\title{
Schwannoma of the tongue: two case reports and review of the literature
}

\author{
Marc Cohen • Marilene B. Wang
}

Received: 6 April 2008 / Accepted: 17 December 2008 / Published online: 8 January 2009

(C) The Author(s) 2009. This article is published with open access at Springerlink.com

\begin{abstract}
The aim of this study was to describe clinicopathologic and radiographic features of two cases of schwannoma involving the oral tongue and to review the literature of this unusual clinical entity. Case reports with review of the pathologic, radiologic and clinical data for two patients with schwannoma of the tongue are reported. Review of the literature of case reports of schwannomas (neurilemmomas) of the tongue from 1955 to 2006 with analysis of the patient's age, gender, presenting symptom(s), tumor size, and surgical approach was undertaken. The two patients in our series presented with painless swelling of the tongue. Transoral excision was performed and pathologic examination confirmed the diagnosis of schwannoma in both the cases. A total of 126 cases of schwannoma of the tongue have been reported in the English literature over the past 51 years. Schwannomas of the tongue typically present in the third decade of life $(33 \%)$, display no gender predilection (52.8\% female; $47.2 \%$ male) and often present as a painless mass (69.6\%). Schwannomas are likely to elicit distressing symptoms when they occur in the posterior one-third of the tongue $(63.2$ vs. $13.5 \%)$ or approach $3 \mathrm{~cm}$ in greatest dimension (33.0 vs. $18.2 \mathrm{~mm}$ ). The vast majority of cases have been treated with transoral excision $(94.8 \%)$. Recurrence after surgical excision has not been reported. Schwannoma of the tongue is a relatively rare tumor of the head and neck. Transoral resection allows for removal of this tumor in a
\end{abstract}

Paper presented at the Triological Society Western Meeting in Rancho Mirage, CA (31 January-2 February 2008).

M. Cohen $(\square) \cdot$ M. B. Wang

Division of Head and Neck Surgery,

UCLA School of Medicine, 10838 Le Conte Ave,

Rm 62-132 CHS, Los Angeles, CA, 90095USA

e-mail:macohen@mednet.ucla.edu manner that precludes recurrence, avoids causing morbidity of tongue function, and remains the standard approach for the treatment of the vast majority of these tumors.

Keywords Schwannoma $\cdot$ Neurilemmoma $\cdot$ Lingual . Tongue

\section{Introduction}

Schwannoma (neurilemmoma) is a benign tumor of nerve sheath origin. These tumors can arise from any nerve covered with a Schwann cell sheath, which include the cranial nerves (except for the optic and olfactory), the spinal nerves, and the autonomic nervous system [1]. When the nerve of origin is small, its association with a given tumor may be difficult to demonstrate. On the other hand, if a larger nerve is the site of origin, the nerve fibers are found to be splayed out over the outer aspect of the capsule rather than incorporated within the mass of the tumor [2].

Approximately $25-45 \%$ of all schwannomas occur in the head and neck [3]. Of these, approximately $1-12 \%$ occur intraorally $[4,5]$ with the tongue being the most common site $[5,6]$. Although several case reports of schwannomas of the tongue exist in the literature, there has been no comprehensive review of the literature since Hatziotis et al. [6]. We present two cases of schwannoma of the tongue and review the available literature of the last 51 years (1955-2006).

\section{Materials and methods}

A PubMed search of the terms "tongue schwannoma," "lingual schwannoma," "tongue neurilemmoma," and "lingual neurilemmoma" was performed with the date range of 
(a)

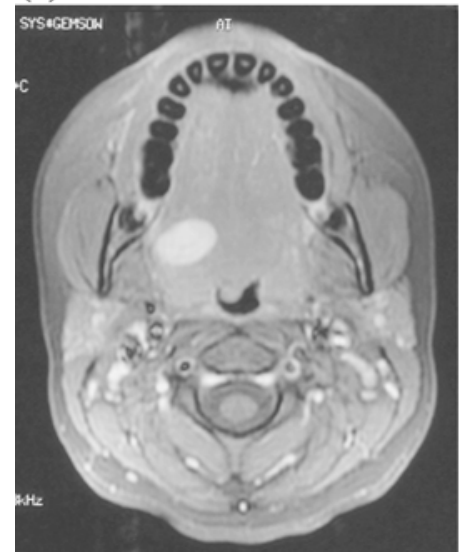

(b)

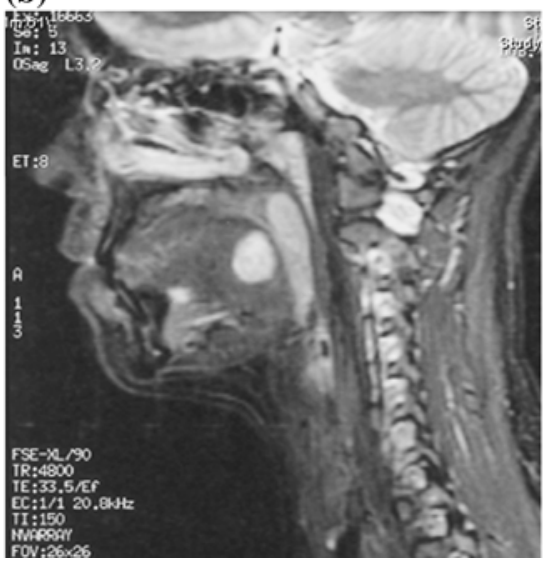

(c)

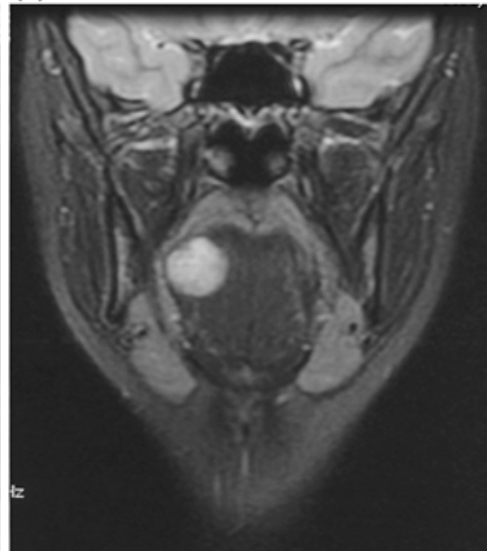

Fig. 1 A well-circumscribed mass is located at right posterior tongue as illustrated by the axial T1 (a), sagittal T2 (b), and coronal T1 (c) magnetic resonance images

1955-2006. The search was limited to case reports in English. Schwannomas of the floor of mouth were not included unless the ventral tongue was also involved. All of the case reports had histologically confirmed the identity of the masses as schwannomas.

The following elements were extracted from the case reports for data analysis: age, gender, location of schwannoma (anterior one-third vs. posterior two-thirds of tongue), presenting symptoms, size of tumor, and treatment modality.

\section{Case reports}

\section{Case report \#1}

An 19-year-old female presented to the Head and Neck Surgery Clinic with complaints of a slowly enlarging painless mass in the back of her throat. A submucosal mass was identified at the right posterolateral tongue. Magnetic resonance (MR) imaging was obtained which illustrated a wellcircumscribed mass in the right posterolateral tongue that was isointense on T1, hyperintense on T2, and enhanced with gadolinium (Fig. 1a-c). The patient was taken to the operating room for a transoral excision under general anesthesia. The mass was submucosal and once a mucosal flap was raised, the tumor was readily shelled out using blunt dissection. The mass had a smooth surface, was tan-white in color, and measured $18 \times 13 \times 11 \mathrm{~mm}$. Final pathology was consistent with schwannoma (Fig. 2a-c).

\section{Case report \#2}

A 77-year-old male was referred to the Head and Neck Surgery Clinic after his dentist noted an $1 \mathrm{~cm}$ firm, sessile mass at the right lateral border of his tongue. The patient reported that the mass had been there for approximately
5 years and had not grown significantly over those years. The patient denied any pain associated with the mass, dysphagia, or change in voice. The mass was excised in clinic under local anesthesia. The mass was gray-tan in color, smooth in texture, dome-shaped, and measured $7 \times 5 \times$ $5 \mathrm{~mm}$. A final diagnosis of schwannoma was ascribed.

\section{Results}

A PubMed search from 1955 to 2006 identified 124 cases of schwannoma of the tongue (Table 1). Of the 126 cases (including the two patients reported in this paper), 106 identified the gender of the patient which showed an almost equal gender predilection with 50 males (47.2\%) and 56 females $(52.8 \%)$. Tongue schwannomas were also noted at all age ranges, but had a significantly higher incidence between the second and fourth decades of life (Fig. 3).

The location of the schwannoma was categorized as either anterior two-thirds or posterior one-third of the tongue. This classification was possible in 56 of the 126 cases with 37 cases occurring anteriorly and 19 cases identified posteriorly.

Descriptions of the patient's clinical symptoms were only found in 57 case reports. The majority of patients presented with an asymptomatic mass $(39 / 57 ; 69.6 \%)$. Of the patients that did present with a symptomatic mass, the most common complaints were throat pain or discomfort, dysphagia, and voice change (Table 2). When the location of the schwannoma and the presence of symptoms were examined, a correlation was identified. Of the 19 patients with posterior one-third tumors, 12 patients reported symptoms $(63.2 \%)$. On the other hand, in the anterior two-thirds group, only five patients reported symptoms (13.5\%).

The exact size of the schwannoma was documented in 53 patients. The average size of the excised tumor in all 

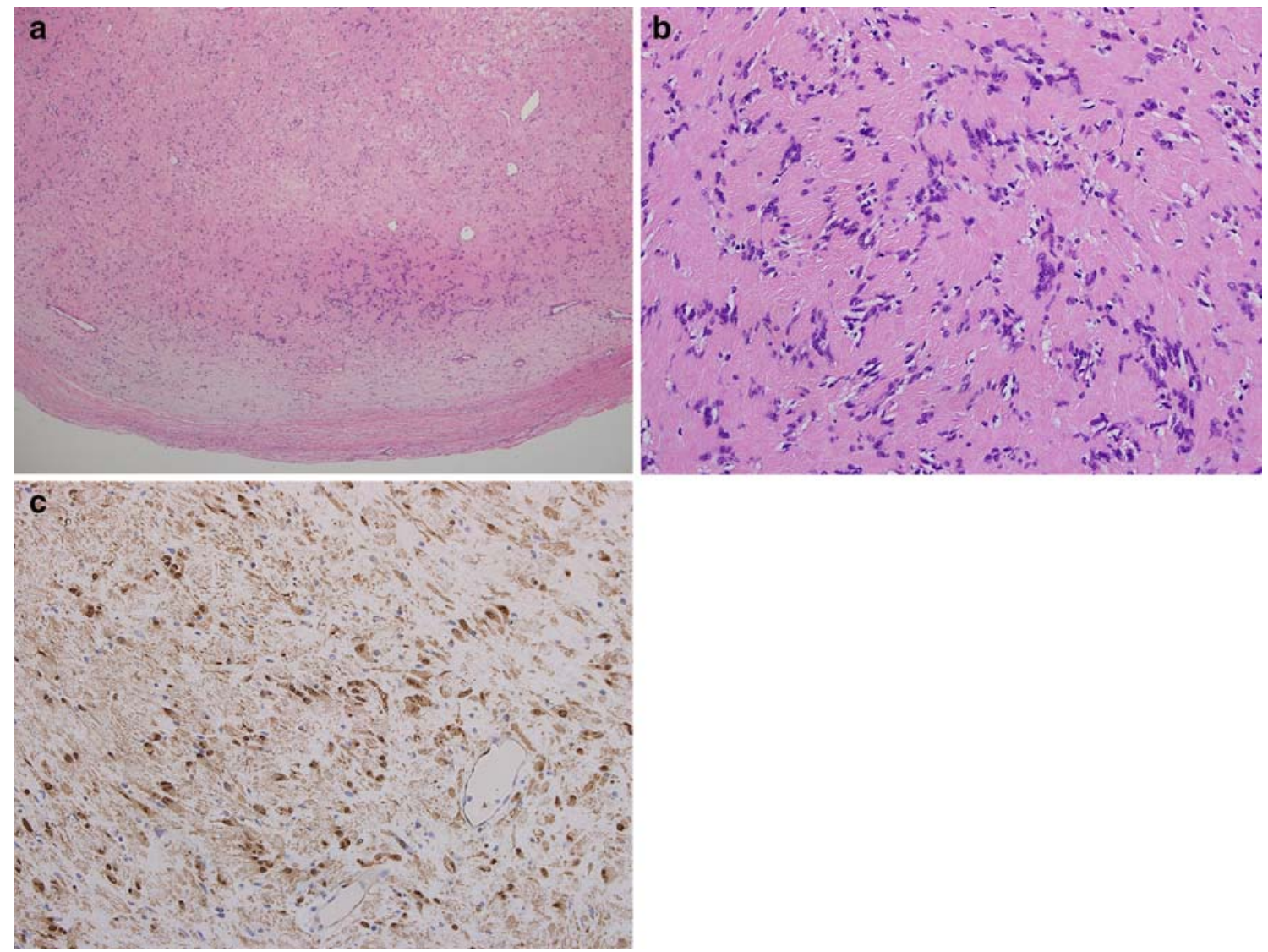

Fig. 2 Schwannoma of the tongue. a At low power $(H \& E, \times 4)$, both Antoni A and Antoni B morphologies can be seen. b At high power (H\&E, $\times 20)$, palisading nuclei and Verocay bodies are noted. $\mathbf{c}$ S-100 is diffusely positive $(\mathrm{S}-100, \times 20)$

documented patients was $24.04 \mathrm{~mm}$. When the size of the tumor was examined between the symptomatic and asymptomatic groups, a clear distinction was noted. The average schwannoma size in the asymptomatic groups was 18.2 versus $33.0 \mathrm{~mm}$ in the symptomatic group.

Almost all schwannomas were excised via a transoral approach $(55 / 58 ; 94.8 \%)$. The remaining patients had their tumors excised via a transhyoid, suprahyoid, or submandibular approach. One patient had a transoral laser excision of the schwannoma.

\section{Discussion}

Schwannoma is a slow-growing benign tumor of the nerve sheath. It originates from the Schwann cell of the peripheral, autonomic, and cranial nerve. It is usually a single, circumscribed, firm, painless lesion of variable size [7]. The etiology of schwannomas is unknown. Approximately $25-45 \%$ of all schwannomas occur in the head and neck [3] with the parapharyngeal space being the most common site [8]. Less commonly, schwannomas present in the oral cavity, and of this subset, the tongue is the most frequently involved $[5,6]$.
In this literature review of the past 51 years, we have identified 126 cases of tongue schwannomas and elucidated some of their characteristics. Schwannomas of the tongue demonstrate an equal gender predilection. The majority of them present as a painless mass. However, as they approach $3 \mathrm{~cm}$ in greatest dimension, they are more likely to produce symptoms such as throat discomfort, dysphagia, and voice changes. Moreover, if the schwannomas arises in the posterior two-thirds of the tongue, they are more likely to produce debilitating symptoms.

Schwannomas usually present as a solitary lesion. When multiple, however, they can be associated with neurofibromatosis. The differentiation between schwannoma and neurofibroma is essential because an apparently "solitary" neurofibroma may be a manifestation of neurofibromatosis [9]. Approximately $15 \%$ of patients with neurofibromatosis will have malignant transformation in one or more lesion, which is in marked contrast to the typical behavior of a schwannoma [10].

Histologically, schwannomas display several features. Virtually, all of these tumors are encapsulated. Beneath this capsule, two main patterns are seen intermingled but sharply defined from each other. The first pattern is referred 
Table 1 Patient and tumor characteristics of tongue schwannomas

\begin{tabular}{|c|c|c|c|c|c|c|}
\hline Author & Year & $\begin{array}{l}\text { Age/ } \\
\text { gender }\end{array}$ & $\begin{array}{l}\text { Location } \\
\text { of tumor }\end{array}$ & $\begin{array}{l}\text { Size (greatest } \\
\text { dimension, } \mathrm{mm} \text { ) }\end{array}$ & $\begin{array}{l}\text { Presenting } \\
\text { symptoms }\end{array}$ & $\begin{array}{l}\text { Surgical } \\
\text { approach }\end{array}$ \\
\hline Cameron [24] & 1959 & $25 \mathrm{M}$ & Anterior & 15 & Painless mass & Transoral \\
\hline Mercantini et al. [25] & 1959 & $22 \mathrm{M}$ & Anterior & 10 & Intermittent pain & Transoral \\
\hline Kragh et al. [2] & 1960 & \multicolumn{5}{|c|}{ Report of 5 cases; patient and tumor characteristics not described } \\
\hline Chadwick [26] & 1964 & $20 \mathrm{~F}$ & Posterior & 22 & Globus & Transoral \\
\hline Craig [27] & 1964 & $8 \mathrm{~F}$ & Posterior & 30 & Painless mass & Transoral \\
\hline Chhatbar [28] & 1965 & $29 \mathrm{M}$ & Posterior & 50 & Throat discomfort & Transoral \\
\hline \multirow[t]{2}{*}{ Pantazopoulos [29] } & \multirow[t]{2}{*}{1965} & $25 \mathrm{M}$ & Anterior & $<10$ & Painless mass & Transoral \\
\hline & & $45 \mathrm{~F}$ & Posterior & 45 & Dysphagia, change in voice & Transoral \\
\hline Firfer et al. [30] & 1966 & $28 \mathrm{~F}$ & Anterior & 30 & Anterior & Transoral \\
\hline \multirow[t]{3}{*}{ Hatziotis et al. [6] } & \multirow[t]{3}{*}{1967} & $25 \mathrm{M}$ & Posterior & "Hazelnut size" & Painless mass & Transoral \\
\hline & & $60 \mathrm{~F}$ & Anterior & "Pea size" & Painless mass & Transoral \\
\hline & & \multicolumn{5}{|c|}{ Report of 46 more cases (18 males, 28 females); patient and tumor characteristics not described } \\
\hline Oles et al. [31] & 1967 & $52 \mathrm{M}$ & Anterior & 10 & Painless mass & Transoral \\
\hline Paliwal et al. [32] & 1967 & $32 \mathrm{M}$ & Anterior & 25 & Painless mass & Transoral \\
\hline $\mathrm{Uj}[33]$ & 1967 & $13 \mathrm{~F}$ & $\mathrm{n} / \mathrm{a}$ & $\mathrm{n} / \mathrm{a}$ & Painless mass & Transoral \\
\hline \multirow[t]{2}{*}{ Crawford et al. [34] } & \multirow[t]{2}{*}{1968} & $24 \mathrm{M}$ & Anterior & 10 & Painless mass & Transoral \\
\hline & & $23 \mathrm{M}$ & Anterior & 5 & Painless mass & Transoral \\
\hline Bititci [35] & 1969 & $40 \mathrm{M}$ & Anterior & 25 & Slight discomfort & Transoral \\
\hline \multirow[t]{2}{*}{ Das Gupta [5] } & 1969 & $21 \mathrm{~F}$ & Posterior & 50 & Pain & Transoral \\
\hline & & \multicolumn{5}{|c|}{ Report of 7 more cases; patient and tumor characteristics not described } \\
\hline Cherrick et al. [11] & 1971 & \multicolumn{5}{|c|}{ Report of 8 cases; patient and tumor characteristics not described } \\
\hline Eversole et al. [12] & 1971 & $58 \mathrm{~F}$ & Anterior & 25 & $\mathrm{n} / \mathrm{a}$ & Transoral \\
\hline Sinha et al. [36] & 1971 & $23 \mathrm{M}$ & Posterior & 15 & Odynophagia & Transoral \\
\hline Mosadomi [37] & 1975 & $19 \mathrm{M}$ & Anterior & 30 & Pain & Transoral \\
\hline Swangsilpa et al. [38] & 1976 & $24 \mathrm{M}$ & Anterior & 30 & Painless mass & Transoral \\
\hline Sharan et al. [39] & 1978 & $30 \mathrm{~F}$ & Anterior & 15 & Change in voice & Transoral \\
\hline Barbosa [40] & 1984 & $12 \mathrm{M}$ & $\mathrm{n} / \mathrm{a}$ & 5 & Painless mass & Transoral \\
\hline Piatelli et al. ${ }^{\mathrm{a}}$ [18] & 1984 & $18 \mathrm{~F}$ & Anterior & $\mathrm{n} / \mathrm{a}$ & Painless mass & Transoral \\
\hline Akimoto et al. [41] & 1987 & $14 \mathrm{M}$ & Anterior & 10 & Painless mass & Transoral \\
\hline Malden [42] & 1988 & $51 \mathrm{~F}$ & Anterior & $\mathrm{n} / \mathrm{a}$ & Painless mass & Transoral \\
\hline \multirow[t]{2}{*}{ Siar et al. [43] } & \multirow[t]{2}{*}{1988} & $17 \mathrm{~F}$ & Posterior & 30 & Painless mass & Transoral \\
\hline & & $13 \mathrm{~F}$ & $\mathrm{n} / \mathrm{a}$ & 44 & $\mathrm{n} / \mathrm{a}$ & Transoral \\
\hline Wilson et al. [44] & 1988 & $78 \mathrm{~F}$ & Posterior & $\mathrm{n} / \mathrm{a}$ & $\mathrm{n} / \mathrm{a}$ & Transoral \\
\hline Flickinger et al. [19] & 1989 & $28 \mathrm{~F}$ & Anterior & 30 & Painless mass & Transoral \\
\hline Talmi et al. [45] & 1991 & $75 \mathrm{~F}$ & Posterior & 10 & Painless mass & Transoral \\
\hline \multirow[t]{2}{*}{ Lopez et al. [4] } & \multirow[t]{2}{*}{1993} & $33 \mathrm{M}$ & $\mathrm{n} / \mathrm{a}$ & 12 & Painless mass & Transoral \\
\hline & & $24 \mathrm{M}$ & Anterior & 6 & Painless mass & Transoral \\
\hline \multirow[t]{2}{*}{ Williams et al. [46] } & \multirow[t]{2}{*}{1993} & $28 \mathrm{M}$ & Anterior & 5 & Painless mass & Transoral \\
\hline & & $58 \mathrm{M}$ & Anterior & 10 & Ulceration & Transoral \\
\hline Haring [47] & 1994 & $49 \mathrm{~F}$ & Anterior & 20 & Painless mass & Transoral \\
\hline Nakayama et al. [13] & 1996 & $40 \mathrm{~F}$ & Anterior & 55 & Painless mass & Transoral \\
\hline Spandow et al. [48] & 1999 & $37 \mathrm{M}$ & Posterior & 79 & Throat discomfort & Transoral \\
\hline de Bree et al. [7] & 2000 & $24 \mathrm{~F}$ & Posterior & 50 & Dysphagia & Submandibular \\
\hline \multirow[t]{2}{*}{ Pfeifle et al. [49] } & \multirow[t]{2}{*}{2001} & $30 \mathrm{~F}$ & Anterior & 10 & Painless mass & Transoral \\
\hline & & $18 \mathrm{M}$ & Anterior & 20 & Painless mass & Transoral \\
\hline Mevio et al. [50] & 2002 & $35 \mathrm{~F}$ & Anterior & 50 & Painless mass & Transoral \\
\hline
\end{tabular}


Table 1 continued

\begin{tabular}{|c|c|c|c|c|c|c|}
\hline Author & Year & $\begin{array}{l}\text { Age/ } \\
\text { gender }\end{array}$ & $\begin{array}{l}\text { Location } \\
\text { of tumor }\end{array}$ & $\begin{array}{l}\text { Size (greatest } \\
\text { dimension, } \mathrm{mm} \text { ) }\end{array}$ & $\begin{array}{l}\text { Presenting } \\
\text { symptoms }\end{array}$ & $\begin{array}{l}\text { Surgical } \\
\text { approach }\end{array}$ \\
\hline Bassichis et al. [51] & 2004 & $9 \mathrm{M}$ & Posterior & 23 & Snoring, difficulty breathing & Transoral \\
\hline Cinar et al. [52] & 2004 & $7 \mathrm{M}$ & Anterior & 10 & Painless mass & Transoral \\
\hline Hwang et al. [53] & 2005 & $23 \mathrm{M}$ & Anterior & 28 & Painless mass & Transoral \\
\hline Vafiadis et al. [54] & 2005 & $18 \mathrm{M}$ & Anterior & 31 & Painless mass & Transoral \\
\hline \multirow[t]{10}{*}{ Hsu et al. [21] } & \multirow[t]{10}{*}{2006} & $39 \mathrm{~F}$ & Anterior & 10 & Painless mass & Transoral \\
\hline & & $39 \mathrm{~F}$ & Posterior & 40 & Dysphagia & Transhyoid \\
\hline & & $9 \mathrm{M}$ & Anterior & 12 & Painless mass & Transoral \\
\hline & & $32 \mathrm{~F}$ & Posterior & 18 & Globus & Transoral \\
\hline & & $25 \mathrm{M}$ & Anterior & 9 & Painless mass & Transoral \\
\hline & & $15 \mathrm{~F}$ & Anterior & 12 & Painless mass & Transoral \\
\hline & & $38 \mathrm{M}$ & Anterior & 30 & Painless mass & Transoral \\
\hline & & $12 \mathrm{~F}$ & Anterior & 16 & Painless mass & Transoral \\
\hline & & $45 \mathrm{M}$ & Anterior & 5 & Painless mass & Transoral \\
\hline & & $20 \mathrm{M}$ & Posterior & 50 & Globus & Transoral \\
\hline Mehrzad et al. [22] & 2006 & $49 \mathrm{M}$ & Posterior & 22 & Throat discomfort & Transoral $\mathrm{CO}_{2}$ laser \\
\hline Ying et al. [20] & 2006 & $26 \mathrm{~F}$ & Posterior & 40 & $\begin{array}{l}\text { Dysphagia, snoring, } \\
\text { change in voice }\end{array}$ & Suprahyoid \\
\hline \multirow[t]{2}{*}{ Cohen and Wang } & \multirow[t]{2}{*}{ Current study } & $18 \mathrm{~F}$ & Posterior & 18 & Painless mass & Transoral \\
\hline & & $77 \mathrm{M}$ & Anterior & 7 & Painless mass & Transoral \\
\hline
\end{tabular}

${ }^{\text {a }}$ Case report of malignant schwannoma of the tongue

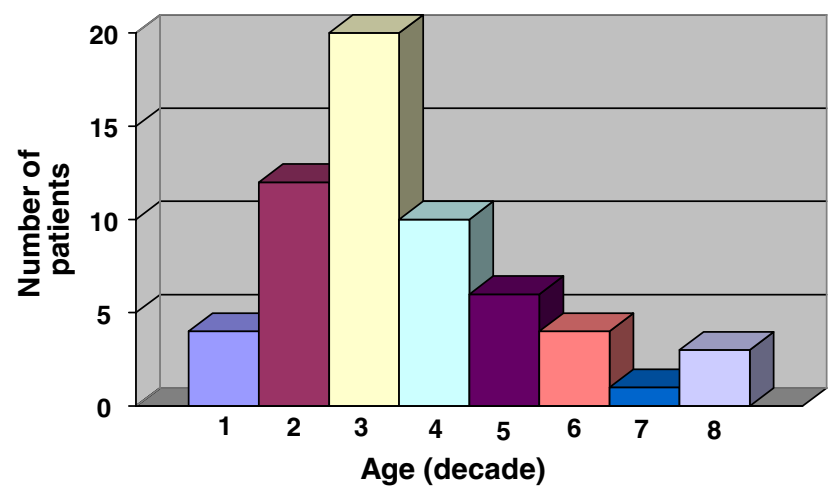

Fig. 3 Age at presentation of patients with tongue schwannomas

to as Antoni type A which consists of closely packed Schwann cells that form bundles or are arranged in rows with palisading, elongated nuclei. Free bands of amorphous substance between rows of nuclei constitute the Verocay bodies. The second pattern is known as Antoni type $B$ and is composed of very loosely arranged Schwann cells set in a meshwork of reticulum fibers and microcysts [11]. In addition to these characteristic patterns, diagnosis is aided by immunohistochemical markers, S-100 and Leu 7, which support the Schwann cell nature of these tumors [4].

Two cases of schwannoma of the tongue were referred to as "ancient" schwannoma $[12,13]$. The term "ancient"
Table 2 Presenting symptoms of patients with tongue schwannomas

\begin{tabular}{ll}
\hline Symptom & $\begin{array}{l}\text { Number of } \\
\text { patients }(n=56)\end{array}$ \\
\hline Painless mass & 39 \\
Throat pain/discomfort & 7 \\
Dysphagia & 4 \\
Change in voice & 3 \\
Globus sensation & 2 \\
Difficulty breathing & 2 \\
Snoring & 2 \\
Ulceration with pain & 1
\end{tabular}

schwannoma was introduced by Ackerman and Taylor [14]. These authors, in addition to others, noted extensive degeneration within the schwannoma and attributed this change to the aging process of the schwannoma. Aside from nuclear atypia, additional changes associated with the degenerative process include formation of cysts, stromal edema, xanthomatous change, and fibrosis. The theorized mechanism is that increasing tumor size results in vascular insufficiency. This hypothesis is supported by the finding that the degenerative changes correlate with tumor size [15]. It is now generally accepted that all schwannomas can demonstrate some degenerative changes and the "ancient" variety probably represents the far end of the continuum of histologic appearance [16]. 
Several cases of malignant transformation of head and neck schwannomas have been reported [2, 17], including one occurrence in the tongue [18]. To support a diagnosis of malignant transformation in benign schwannoma, the following features should be confirmed: (a) the tumor demonstrates, to some extent, benign schwannoma; (b) the tumor contains unequivocal malignant foci as manifested by the presence of increased cellularity, numerous mitoses, anaplastic cells, and invasiveness; (c) transitional features between malignant and benign areas can be seen; and (d) the patient has no evidence of von Recklinghausen's disease [13].

The imaging modality of choice for schwannomas of the tongue is MR. MR is superior to computed tomography (CT) in several aspects. The MR image is not degraded by dental amalgam or the beam-hardening artifacts that plague CT scanning of the oral cavity. In addition, MR allows an accurate measurement of tumor size and precise localization in relation to other structures. On MR, tongue schwannomas appear isointense to muscle on T1-weighted images and homogenously hyperintense on $\mathrm{T} 2$-weighted images. Moreover, these tumors usually appear smooth, well demarcated, and do not invade the surrounding musculature [19].

All reported cases of schwannomas of the tongue have been treated by surgical excision. The most common approach was the transoral route. This is an obvious choice for approaching these tumors since most are easily accessible via this route. Several other approaches have also been reported to have success including submandibular [7], suprahyoid pharyngotomy [20], and transhyoid [21] approaches. All of these approaches were used for base of tongue schwannomas that were deemed difficult to approach by the transoral route. More recently, the use of $\mathrm{CO}_{2}$ laser for excision of a base of tongue schwannoma has also been reported [22]. The goal of surgical therapy is to complete resection. If this is accomplished, recurrence is rare [21].

In evaluating a patient with a slow-growing tongue mass that has been present for a long period of time, benign soft tissue neoplasms and reactive lesions need to be considered. In addition to schwannomas, the differential diagnosis should include neurofibromas, granular cell tumors, irritation fibromas, leiomyomas, rhabdomyomas, hemangiomas, lymphangiomas, lipomas, pyogenic granulomas, and benign salivary gland tumors [23]. Malignant etiologies should always be considered, but are unlikely to present with the slow clinical course that is typical of a schwannoma.

\section{Conclusions}

Schwannoma of the tongue is a relatively rare tumor of the head and neck. Transoral resection allows for removal of this tumor in a manner that precludes recurrence, avoids causing morbidity of tongue function, and remains the standard approach for treatment of the vast majority of these tumors. The chance of malignant transformation of these tumors is exceedingly unlikely.

\section{Conflict of interest statement None.}

Open Access This article is distributed under the terms of the Creative Commons Attribution Noncommercial License which permits any noncommercial use, distribution, and reproduction in any medium, provided the original author(s) and source are credited.

\section{References}

1. Zachariades N (1984) Schwannoma of the oral cavity: review of the literature and report of a case. J Oral Med 39:41-43

2. Kragh LV, Soule EH, Masson JK (1960) Benign and malignant neurilemmomas of the head and neck. Surg Gynecol Obstet 111:211-218

3. Katz AD, Passy V, Kaplan N (1971) Neurogenous neoplasms of major nerves of head and neck. Arch Surg 103:51-56

4. Lopez JI, Ballestein C (1993) Intraoral schwannoma: a clinicopathologic and immunohistochemical study of nine cases. Arch Anat Cytol Pathol 41:18-23

5. Das Gupta TK, Brasfield RD, Strong EW, Hajdu SI (1969) Benign solitary schwannomas (neurilemmomas). Cancer 24:355-366. doi:10.1002/1097-0142(196908)24:2<355::AIDCNCR2820240218>3.0.CO;2-2

6. Hatziotis JC, Asprides H (1967) Neurilemoma (schwannoma) of the oral cavity. Oral Surg Oral Med Oral Pathol 24:510-526. doi:10.1016/0030-4220(67)90431-8

7. de Bree R, Westerveld G-J, Smeele LE (2000) Submandibular approach for excision of a large schwannoma in the base of tongue. Eur Arch Otorhinolaryngol 257:283-286. doi:10.1007/ s004050050241

8. Franzen A, Koegel K (1996) Neurinome im Halsbereich. Laryngorhinootologie 75:250-253. doi:10.1055/s-2007-997571

9. Sardinha SDCS, Paza AO, Vargas PA, Moreira RW, de Moraes M (2005) Schwannoma of the oral cavity. Histological and immunohistochemical features. Braz J Oral Sci 4:806-809

10. Wright BA, Jackson D (1980) Neural tumors of the oral cavity. A review of the spectrum of benign and malignant oral tumors of the cavity and jaws. Oral Surg Oral Med Oral Pathol 49:509-522. doi:10.1016/0030-4220(80)90075-4

11. Cherrick HM, Eversole LR (1971) Benign neural sheath neoplasm of the oral cavity. Oral Surg Oral Med Oral Pathol 32:900-909. doi:10.1016/0030-4220(71)90177-0

12. Eversole LR, Howell RM (1971) Ancient neurilemmoma of the oral cavity. Oral Surg Oral Med Oral Pathol 32:440-443. doi:10.1016/0030-4220(71)90204-0

13. Nakayama H, Gobara R, Shimamoto F, Kajihara H (1996) Ancient schwannoma of the oral floor and ventricular portion of the tongue: a case report and review of the literature. Jpn J Clin Oncol 26:185-188

14. Ackerman LV, Taylor FH (1951) Neurogenous tumors within the thorax: a clinicopathologic evaluation of forty-eight cases. Cancer 4:669-691. doi:10.1002/1097-0142(195107)4:4<669::AID-CN CR2820040405>3.0.CO;2-B

15. Vilanova JR, Burgos-Bretones JJ, Alvarez JA, Rivera-Pomer JM (1982) Benign schwannomas: a histopathological and morphometric study. J Pathol 137:281-286. doi:10.1002/path.1711370403

16. Dodd LG, Marom EM, Dash RC, Matthews MR, McLendon RE (1999) Fine-needle aspiration cytology of "ancient" schwannoma. 
Diagn Cytopathol 20:307-311. doi:10.1002/(SICI)1097-0339 (199905)20:5<307::AID-DC12>3.0.CO;2-F

17. Colreavy MP, Lacy PD, Hughes J et al (2000) Head and neck schwannomas-a 10 year review. J Laryngol Otol 114:119-124. doi:10.1258/0022215001905058

18. Piatelli A, Angelone A, Pizzicannella G, Piatelli M (1984) Malignant schwannoma of the tongue: report of a case and review of the literature. Acta Stomatol Belg 81:213-225

19. Flickinger FW, Lozano RL, Yuh WTC, Sachs MA (1989) Neurilemoma of the tongue: MR findings. J Comput Assist Tomogr 13:886-888. doi:10.1097/00004728-198909000-00025

20. Ying Y-LM, Zimmer LA, Myers EN (2006) Base of tongue schwannoma: a case report. Laryngoscope 116:1284-1287. doi:10.1097/01.mlg.0000224358.55022.8a

21. Hsu Y-C, Hwang C-F, Hsu R-F, Kuo F-Y, Chen C-Y (2006) Schwannoma (neurilemmoma) of the tongue. Acta Otolaryngol 126:861-865. doi:10.1080/00016480500527219

22. Mehrzad H, Persaud R, Papadimitriou N, Kaniyur S, Mochloulis G (2006) Schwannoma of the tongue base treated with transoral carbon dioxide laser. Lasers Med Sci 21:235-237. doi:10.1007/ s10103-006-0402-1

23. Nelson W, Chuprevich T, Galbraith DA (1998) Enlarging tongue mass. J Oral Maxillofac Surg 56:224-227. doi:10.1016/S02782391(98)90873-4

24. Cameron IW (1959) A case of neurilemmoma (schwannoma) of the tongue. Oral Surg Oral Med Oral Pathol 12:1464-1467. doi:10.1016/0030-4220(59)90270-1

25. Mercantini ES, Mopper C (1959) Neurilemmoma of the tongue. AMA Arch Derm 79:542-544

26. Chadwick DL (1964) Neurilemmoma of the tongue. J Laryngol Otol 78:959-962. doi:10.1017/S0022215100063027

27. Craig RDP (1964) Neurilemmoma of the tongue. Arch Dis Child 39:397-398

28. Chhatbar DR (1965) A case of neurilemmoma of the tongue. J Laryngol Otol 79:170-174. doi:10.1017/S0022215100063520

29. Pantazopoulos PE (1965) Schwannomas of nose, oral cavity, and pharynx. Acta Otolaryngol 60:97-104. doi:10.3109/ 00016486509126992

30. Firfer H, Sohn D, Heurlin R, Stuteville OH (1966) Neurilemmoma of the tongue. Oral Surg Oral Med Oral Pathol 21:139-142. doi:10.1016/0030-4220(66)90231-3

31. Oles RD, Wertheimer FW (1967) Neurilemmoma of the tongue. J Mich State Dent Assoc 49:7-8

32. Paliwal YD, Kapur VL, Singh RP (1967) Neurilemoma of the tongue. Int Surg 47:503-506

33. Uj J (1967) Neurinoma of the tongue: report of a case. Oral Surg Oral Med Oral Pathol 23:787-788. doi:10.1016/0030-4220(67) 90370-2

34. Crawford WH, Korchin L, Greskovich FJ Jr (1968) Neurilemmomas of the oral cavity: report of five cases. J Oral Surg (Chic) 26:651-658. doi:10.1016/0030-4220(68)90432-5
35. Bititci OO (1969) Neurilemmoma of the tongue. J Laryngol Otol 83:201-204. doi:10.1017/S0022215100070237

36. Sinha SN, Samuel KC (1971) Neurilemmoma of tongue. J Laryngol Otol 85:623-626. doi:10.1017/S0022215100073904

37. Mosadomi A (1975) Neurilemmoma of the tongue. J Oral Med 30:44-46

38. Swangsilpa K, Winther JE, Nybroe L (1976) Neurilemmomas in the oral cavity. J Dent 4:237-241. doi:10.1016/0300-5712(76)90055-5

39. Sharan R, Akhtar MP (1978) Neurilemmoma of tongue. J Indian Med Assoc 71:290-291

40. Barbosa J, Hansen LS (1984) Solitary multilobular schwannoma of the oral cavity. J Oral Med 39:232-235

41. Akimoto Y, Yamamoto H, Nishimura H, Komiya M, Kaneko K (1987) Neurilemmoma in the oral cavity. J Nihon Univ Sch Dent 29:203-205

42. Malden NJ (1988) Neurilemmoma of the tongue. Dent Update 15:170

43. Siar CH, Ng KH, Chia TY, Kulkarni MG (1988) Atypical neurilemmomas of the tongue: report of two cases. Singapore Med J 29:83-85

44. Wilson JA, McLaren K, McIntyre MA, von Haacke NP, Maran AG (1988) Nerve-sheath tumors of the head and neck. Ear Nose Throat J 67:103-107 110

45. Talmi YP, Gal R, Finkelstein Y, Shvilli Y, Zohar Y (1991) Pathologic quiz case 1: benign schwannoma of tongue. Arch Otolaryngol Head Neck Surg 117:926-928

46. Williams HK, Cannell H, Silvester K, Williams DM (1993) Neurilemmoma of the head and neck. Br J Oral Maxillofac Surg 31:32-35. doi:10.1016/0266-4356(93)90094-D

47. Haring JI (1994) Case \#10. Neurilemmoma. RDH 14:12

48. Spandow O, Fagerlund M, Bergmark L, Boquist L (1999) Clinical and histopathological features of a large parapharyngeal neurilemmoma located at the base of tongue. ORL 61:25-30. doi:10.1159/ 000027634

49. Pfeifle R, Baur DA, Paulino A, Helman J (2001) Schwannoma of the tongue: report of 2 cases. J Oral Maxillofac Surg 59:802-804. doi:10.1053/joms.2001.24298

50. Mevio E, Gorini E, Lenzi A, Migliorini L (2002) Schwannoma of the tongue: one case report. Rev Laryngol Otol Rhinol (Bord) 123:259-261

51. Bassichis BA, McClay JE (2004) Pedunculated neurilemmoma of the tongue base. Otolaryngol Head Neck Surg 130:639-641. doi:10.1016/j.otohns.2003.09.029

52. Cinar F, Cinar S, Harman G (2004) Schwannoma of the tip of the tongue in a child. Plast Reconstr Surg 114:1657-1658

53. Hwang K, Kim SG, Ahn SI, Lee SI (2005) Neurilemmoma of the tongue. J Craniofac Surg 16:859-861. doi:10.1097/01.SCS. 0000164333.81428.F3

54. Vafiadis M, Fiska A, Panopoulou M, Assimakopoulos D (2005) A clinical case report of a Schwannoma on the tip of the tongue. B-ENT 1:201-204 